\title{
Performance of Kenyan Listed Companies Pre and Post Chief Executive Officer Dismissal, Retirement and Resignation Events
}

\author{
James N Ndegwa ${ }^{1}$ \\ ${ }^{1}$ Department of Accounting and Finance, School of Business and Economics, The Cooperative University of \\ Kenya \\ Correspondence: James N Ndegwa, Department of Accounting and Finance, School of Business and Economics, \\ The Cooperative University of Kenya. E-mail: jndegwa@cuk.ac.ke / ndegwajam@gmail.com
}

Received: November 15, 2018

Accepted: December 26, 2018

Online Published: January 27, 2019

doi:10.5539/ijbm.v14n2p180

URL: https://doi.org/10.5539/ijbm.v14n2p180

\begin{abstract}
In the decade between years 2001 - 2011 Kenya experienced change of CEOs of listed firms through dismissal, resignation and retirement which created a need to establish whether CEO departure events had a significant influence on stock returns and profitability of the affected firms. In this research 9 CEO departure events 3 dismissal, 3 retirement and 3 resignation events were analyzed. Abnormal stock returns were computed by employing the market model and profitability of the affected listed firms was measured by employing return on assets (ROA). Paired samples t-test was employed to examine whether there was a significant difference in the abnormal returns and profitability (ROA) during pre and post CEO departure period. The findings indicated that there was no significant difference in abnormal stock returns and profitability in the pre and post CEO departure events. The findings implied that NSE investors were not excited by change of CEOs and that the NSE is semi strong form efficient.
\end{abstract}

Keywords: chief executive officers dismissal, retirement and resignation events

\section{Background of the Study}

Kenyan listed companies have in the recent years experienced CEO departures due to various reasons including poor financial performance of the companies that they manage. In most cases, the performance of CEOs is usually pegged on the financial performance of the firms that they manage (Magnan, Thorne, \& Raymond, 2010). Financial performance of firms have been found to be more variable in firms where CEOs have greater power to influence decisions especially where the CEOs are also the founders of the firm (Adams, Almeida and Ferreira, 2005). This research focused on analyzing the profitability and stock performance of Kenyan listed companies during pre and post CEO departure events.

The leadership capability of chief executive officers CEOs and their entrepreneurship skills are key strategic resources that can determine a firm's growth and performance ( $\mathrm{Wu}, 2014)$. CEOs are known to possess various types of power to enable them steer firms in the right direction including: legitimate power of being influential by virtue of the senior positions in firms. CEOs also possess expert power of having technical information or specific and unique skills that are respected. Some CEOs possess coercive power and hence are able to discourage undesired actions of others. By having reward power CEOs are able to encourage desired actions of others. Referent power enables CEOs to use their strong interpersonal skills, charm, attractive personality and charisma to influence others positively (Schepker, 2012; Gonglaves, 2013).

Change of CEO may be as a result of dismissal, resignations, retirement and even death (Wu, 2014). For poorly performing firms, CEO dismissal is seen as the ultimate punishment by the board of directors (Wiersema, 2002). Financial wrongdoings may be an important reason causing the resignation of CEOs especially due to external pressure from stakeholders (Wu, 2014). Planned CEO retirements are regarded to be generally smooth and often involve successors who are well known to the incumbent CEO (Ishak, Ismail and Abdulla, 2014). In Kenya listed firms have had CEO dismissal, resignation and retirement events but no CEO has died while in office during the study period of this research.

\subsection{Motivation of the Study}

Stock market investors are on the lookout for any information that can assist them in outperforming the market 
and hence generate profits for them in the form of abnormal stock returns. However, all past relevant information is assumed to be already incorporated in stock prices in weak form efficient markets while all publicly available information is deemed to be already incorporated in stock prices in semi strong form efficient markets (Fama, 1991). Due to the key positions that CEOs occupy in firms, it is expected that if a CEO departs from the position that would make news and cause significant effect on stock prices and returns if the market is weak form efficient and if semi strong form efficient, CEO departure would go unnoticed as far as stock prices and returns are concerned (Fama, 1991).

Most research on CEO succession and other corporate governance mechanisms has been conducted on U.S. firms and there has been limited research on the firm performance after CEO departure (Bresser et al., 2005). Previous studies in Kenya also indicate mixed results regarding the relationship between change of CEOs and firm performance as some companies have posted positive post succession performance while others had the same level of return or even poor returns in the post succession period (Ondieki, 2011) and hence the motivation for the current.

\subsection{Research Objectives}

1. To assess whether there is a difference in abnormal stock returns associated with the dismissal, retirement and resignation of CEOs from Kenyan listed companies

2. To test whether there is a difference in profitability associated with dismissal, retirement and resignation of CEOs from Kenyan listed companies

\section{Theoretical Literature Review}

\subsection{Efficient Market Hypothesis}

Efficient market hypothesis was developed by Eugene Fama (1965). The theory posits that in weak form efficient markets stock prices occur in a random manner making it impossible to outperform such markets by employing past information. The theory also posits that it not possible to employ publicly available information or past information to outperform semi-strong form efficient markets. Strong form efficient markets cannot be outperformed by employing past or publicly available or even privately held information according to the theory. The main implication of efficient market hypothesis is that investors should trust market prices and that in efficient markets investors get value for money (Fama, 1991). NSE has in the past been deemed as weak form efficient and thus making it possible to outperform it by employing of new information that is yet to be incorporated in the stock prices in the form of events like CEO departure.

\subsection{Agency Theory}

Agency theory (Jensen and Meckling, 1976) shows the relationship between the principal and agent and explores the conflict that usually arises between the principal and agent due to their different interests where managers are interested in remuneration and fringe benefits while the owners who are the principals are interested in maximization of their wealth. Agency theory asserts that managers are not fully interested in maximizing shareholders wealth and hence the source of conflict between the managers and owners. The owners thus employ a variety of manager performance monitoring mechanisms to safeguard their interests in the firm. CEOs being agents of firm owners may not necessarily have the same objectives as the firm owners and hence the pegging of the rewards to CEOs on the firm performance to act as an incentive for improved performance.

\subsection{Stewardship Theory}

Stewardship theory argues that managers are inherently trustworthy and not prone to misappropriate corporate resources. Managers are deemed to be stewards whose behaviors are supposed to be aligned with their principals who are the owners of resources (Donaldson, 1990). This is a contradiction to the agency theory that deems that the objectives of managers are not aligned with those of shareholders (Maher and Anderson, 1999). If the incentive schemes are crafted in a manner that makes CEOs part owners of the firms say through executive stock options, the CEOs objectives are likely to be aligned to those of firm owners.

\subsection{Empirical Literature Review}

Bresser et al., (2005) studied the performance implications of CEO dismissals: evidence from a stakeholder environment when considering ROA and EBIT/TA, data on 91 sample succession events on all large German stock companies (DAX 100) was collected for the years 1998 - 2003. Three accounting measures of performance and one market measure are utilized: operating earnings to total assets (EBIT/TA), return on assets (ROA), sales growth (SG), and total return to the firm's shareholders (RTS). The results indicated that firms with fired CEOs have significantly lower pre-succession accounting performance than their industry counterparts or 
firms with routine CEO succession events. The results also indicated that there was relative improvement of operating earnings when dismissal firms are contrasted with routine succession firms and that firms that have dismissed their CEO have (in some cases significantly) lower post-succession accounting and market performance than pre-succession performance.

Kiogora, (2012) studied the relationship between chief executive officer turnover and firm performance, for companies quoted at the Nairobi Securities Exchange. A descriptive cross sectional research design was employed and 17 Kenyan listed firms were sampled for the study. The results indicated that there exists a positive relationship between CEO turnover and firm performance which implied that CEO turnover or change can be employed to enhance the performance of a poorly performing firm.

Jenter and Kanaan, (2015) studied CEO turnover and relative performance evaluation. They collected sample of 3,365 CEO turnovers from 1993 to 2009 . The study employed regression analysis. The results indicated that CEOs are fired after bad firm performance caused by factors beyond their control. CEOs are significantly more likely to be dismissed from their jobs after bad industry and, to a lesser extent, after bad market performance. The results also indicated that a decline in industry performance from the $90^{\text {th }}$ to the 10th percentile doubles the probability of a forced CEO turnover.

\section{Research Methodology}

\subsection{Research Design}

This study used quantitative research design and focused on collecting and analyzing stock return and profitability data of listed companies in Kenya.

\subsection{Population and Sampling}

In this research the target population was the 24 firms listed in the NSE that were affected by CEO departure during the study period of years 2001 to 2014. A sample of 9 CEO dismissal, retirement and resignation events were selected using purposive sampling method and consisted of 3 CEO dismissal events, 3 CEO retirement events and 3 CEO resignation events as per Appendix 1. There was no CEO death while in office events during the study period.

\subsection{Data Collection Method}

Secondary data in the form of stock and market returns was derived from closing stock price data and closing NSE 20 share index data that were derived from the NSE daily trading records. The profitability data was derived from annual reports of the listed firms. For each CEO departure event, stock returns for 240 days were studied and initially divided into pre-event period data of 180 days for the purpose of development of the market asset pricing prediction model and an event period of 60 days for the purpose of testing the prediction model. The 60 days were further divided into 30 days pre and 30 days post CEO departure event (Mac Kinlay, 1997).

\subsection{Data Analysis Procedure}

The event study methodology was employed in the generation of abnormal returns by employing the following procedure (Darrell, 2010): the stock returns were generated from stock prices using simple arithmetic return $\left(R_{t}\right)$ model follows:

$$
\mathbf{R}_{\mathrm{t}}=\left(\mathbf{P}_{\mathrm{t}} / \mathbf{P}_{\mathrm{t}^{-1}}\right)-\mathbf{1}
$$

Where: $\mathrm{P}_{\mathrm{t}}=$ today's closing stock price and

$\mathrm{P}_{\mathrm{t}^{-1} 1}=$ yesterday's closing stock price

The estimated or required rate of return (RRR) for each company stock involved was determined by employing the market asset pricing model which is an application of simple regression analysis. The market asset pricing model employed was as follows (Mac Kinlay, 1997):

$$
\mathbf{R R R}=\boldsymbol{\alpha}+\boldsymbol{\beta}\left(\mathbf{R}_{\mathrm{m}}\right)
$$

Where: $\mathrm{R}_{\mathrm{m}}=$ NSE market return,

$\alpha=$ constant and

$\beta=$ coefficient

In the market model, the daily stock returns of each company formed the dependent variable of the model and the corresponding market returns derived from the daily NSE 20 share index formed the independent variable. The pre-dismissal, retirement and resignation event period employed was 180 days while the event period was 60 days consisting of 30 days before and 30 days after the CEO dismissal, retirement and resignation 
announcements (Mac Kinlay, 1997).

The abnormal returns (AR) were computed as follows:

$$
A R=R_{t}-\mathbf{R R}
$$

Where: $\mathrm{R}_{\mathrm{t}}=$ actual returns

$R R R=$ required rate of return or estimated return

The average abnormal returns (AAR) were computed for each day from 20 days before and 20 days after the dismissal, retirement and resignation announcements. This was done by averaging the abnormal returns as follows:

$$
\mathbf{A A R}=\Sigma \mathbf{A R} / \mathbf{n}
$$

Where: $\mathrm{n}=$ number of firms is sample

The abnormal returns were thereafter compared for significant difference before and after CEO dismissal, retirement and resignation event by employing the paired samples t-test technique. The hypothesis for paired sample t-test is H0: there is no significant difference between the means of the two groups and the H1: there is a significant difference between the means of the two groups. The paired samples t-test technique modeled as follows (Shah and Arora, 2014):

$$
\text { Paired } \mathbf{t}=\left(\sum \mathbf{d} / \mathbf{n}\right) /\left[\sqrt{ } \sum \mathbf{d}^{2}-\left(\sum \mathbf{d}\right)^{2} / \mathbf{n}\right] / \mathbf{n}-\mathbf{1}
$$

Where: $\mathrm{d}=$ difference in matched scores, $\mathrm{n}=$ number of matched scores

The second research objective on examining whether there was significant difference in profitability was measured using return on assets (ROA) ratio before and after dismissal, retirement and resignation of CEOs from Kenyan listed companies. The significant difference in ROA before and after dismissal, retirement and resignation of CEOs was also tested by employing the paired samples t-test method. The return on assets was derived using the following ratio:

$$
\text { ROA }=\text { PAT } / \text { TNA }
$$

Where: PAT $=$ profit or loss after tax

$\mathrm{TNA}=$ total net assets

$\mathrm{ROA}=$ return on assets

\section{Research Findings}

The findings in Table 1 indicated p-values of $0.611,0.907$ and 0.994 for abnormal returns relating to CEO dismissal, retirement and resignation events respectively. This implied that the null hypothesis of lack of significant difference in abnormal returns during pre and post CEO departure events was not rejected. This

\begin{tabular}{|c|c|c|c|c|c|c|}
\hline \multicolumn{2}{|c|}{ Paired Variables } & \multirow{2}{*}{$\begin{array}{l}\text { Paired Mean Differences } \\
-0.3761\end{array}$} & \multirow{2}{*}{$\frac{\text { Std. Deviation }}{4.00372}$} & \multirow{2}{*}{$\begin{array}{l}\mathbf{t} \\
-0.515\end{array}$} & \multirow{2}{*}{$\frac{\text { df }}{29}$} & \multirow{2}{*}{$\frac{\text { p-value }}{0.611}$} \\
\hline Pair 1 & $\begin{array}{l}\text { CEO dismissal } \\
\text { Events }\end{array}$ & & & & & \\
\hline Pair 2 & $\begin{array}{l}\text { CEO retirement } \\
\text { events }\end{array}$ & -0.0444 & 2.06938 & -0.118 & 29 & 0.907 \\
\hline Pair 3 & $\begin{array}{l}\text { CEO resignation } \\
\text { events }\end{array}$ & 0.0036 & 2.6224 & 0.008 & 29 & 0.994 \\
\hline
\end{tabular}
further implied that CEO departure events in the NSE are not significant enough to cause stock price and stock return changes and that NSE is efficient in at least the weak form.

Table 1. Paired samples test of abnormal returns during CEO departure events

The findings in Table 2 indicated p-values of $0.629,0.672$ and 0.051 for ROA relating to CEO dismissal, retirement and resignation events respectively. This also implied that the null hypothesis of lack of significant difference in ROA in the pre and post CEO departure events was also not rejected. Hence CEO departure events in the NSE are not significant enough to cause stock price and stock return changes and further evidence of NSE being efficient in at least the weak form. 
Table 2. Paired samples test of profitability (ROA) during CEO departure events

\begin{tabular}{lllllll} 
Paired Variables & Paired Mean Differences & Std. Deviation & t & df & p-value \\
\hline Pair 1 & $\begin{array}{l}\text { CEO dismissal } \\
\text { events }\end{array}$ & -0.0751 & 0.42002 & -0.506 & 7 & 0.629 \\
Pair 2 & $\begin{array}{l}\text { CEO retirement } \\
\text { events }\end{array}$ & 0.02376 & 0.16198 & 0.44 & 8 & 0.672 \\
Pair 3 & $\begin{array}{l}\text { CEO resignation } \\
\text { events }\end{array}$ & -0.1144 & 0.14962 & -2.295 & 8 & 0.051 \\
\hline
\end{tabular}

\section{Conclusion and Discussion}

With regard to the first objective on testing whether there was significant difference in abnormal returns before and after CEO dismissal, retirement and resignation events, the NSE participants appear to be indifferent about the CEO dismissal, retirement and resignation events. This implies that there are events which investors take notice off and events that investors do not give a lot of value. With respect to the second objective on testing whether there was a significant difference in ROA ratio before and after CEO dismissal, retirement and resignation events, NSE listed firms performance is unaffected by CEO changes. The findings that CEO events do not have a significant effect on abnormal stock returns in the NSE are contrary to those of Ndegwa and Kiweu (2013) who found that bonus declaration events had a significant effect on abnormal returns in the NSE.

\section{Policy Implications}

Investors should not be alarmed by CEO changes in NSE listed firms as there are no profit opportunities whether in terms of capital gains or dividends. From the findings NSE appears to now be semi strong efficient.

\section{References}

Adams, R. B., Almeida, H., \& Ferreira, D. (2005). Powerful CEOs and their Impact on Corporate Performance. Review of Financial Studies, 18(4), 1403-1432. Retrieved from https://experts.illinois.edu/en/publications/powerful-ceos-and-their-impact-on-corporate-performan

Bai, J., \& Serena, N. (2005). Test of Skewness, Kurtosis and Normality for Time Series Data. Journal of Business and Economic Statistics, 23(1), 49-60. https://www.jstor.org/stable/27638793

Bresser, R. K., Thiele, R. V., Biedermann, A., \& Lüdeke, H. (2005). Performance Implications of CEO Dismissals: Evidence from a Stakeholder Environment. Presented at the 25th Annual International Conference Strategic Management Society, 2005, Orlando, USA

Darrell, A. J. (2010). Insider Trading: A Test of Market Efficiency. Proceedings of ASBBS Annual Conference, $17(1), 174-181$.

Denis, D., \& Denis, D. (1995).Performance changes following top management dismissals. The Journal of Finance, 1(4), 1029-1057. https://doi.org/10.1111/j.1540-6261.1995.tb04049.x

Donaldson, L., \& Davis, J. H. (1991). Stewardship Theory or Agency Theory: CEO Governance and Shareholder Returns. Australian Journal of Management, $16(1), \quad$ 14-65. https://pdfs.semanticscholar.org/b226/d681d20fb646b147ecb3f452fb5de2269cb7.pdf

Donaldson, T., \& Preston, L. E. (1995). The Stakeholder Theory of the Corporation: Concepts, Evidence and Implications. The Academy of Management Review, 20(1), 65-91. Retrieved from http://faculty.wwu.edu/dunnc3/rprnts.stakeholdertheoryofcorporation.pdf

Fama E. F (1991). Efficient Capital Markets II. Journal of Finance, 24(5). http://viking.som.yale.edu/will/research.papers/fama_91.pdf

Fredrickson, J. W., Hambrick, D. C., \& Baumrin, S. (1988). A Model of CEO Dismissal. The Academy of Management Review, 255-270. https://www.researchgate.net/publication/308181581_CEO_succession_what_we_know_and_where_to_go

Goncalves, M. (2013). Leadership and Power to Influence. International Journal of Business and Social Sciences, 4(4), 1-3. http://ijbssnet.com/journals/Vol_4_No_4_April_2013/1.pdf

Ishak, R., Ismail, K., \& Abdulla, S. N. (2014). CEO Succession and Firm Performance: Evidence from Publicly Listed Malaysian Firms. Asian Academy of Management Journal of Accounting and Finance, 9(2), 29-48. 
http://web.usm.my/journal/aamjaf/vol\%209-2-2013/AAMJAF\%209-2-art\%202\%20(29-48)-edited.pdf

Jensen, M. C., \& Meckling, W. H. (1976). Theory of the firm: Managerial behavior, agency costs and ownership structure. Journal of Financial Economics, 4(3), 305-360.

Jenter, D., \& Kaanan, F. (2015). CEO Turnover and Relative Performance Evaluation. Journal of Finance, 70(5), 2155-2184.

Kiogora, D. N (2012). The Relationship between Chief Executive Officer Turnover and Firm Performance, for Companies Quoted at The Nairobi Securities Exchange. Unpublished MBA Thesis, School of Business, University of Nairobi.

Larson, S. J., \& Madura, J. (2003). What Drives Stock Price Behavior Following Extreme One-Day Returns. Journal of Financial Research, 26(1), 113-127.

Mac Kinlay, A. C. (1997). Event Studies in Economics and Finance. Journal of Economic Literature, 13-39. Retrieved from https://pdfs.semanticscholar.org/aac6/83a678a12a3dcd73389aac7289868847ea73.pdf

Maher, M., \& Anderson, T. (1999). Corporate Governance: Effects on Firm Performance and Economic Growth. Organization for Economic Co-operation and Development, Corporate Ownership \& Control, 2(2), 11-27.

Ndegwa, J. N., \& Kiweu, J. M. (2013). Is There Profit from Bonus Share Announcements in Nairobi Securities Exchange? Research. Journal of Finance and Accounting, 4(8), 10-17. Retrieved from https://www.iiste.org/Journals/index.php/RJFA/article/view/6689

Ondieki, S. (2011). The Effect of Chief Executive Officer Change Announcements on The Stock Returns of Firms Listed at The Nairobi Stock Exchange. unpublished MBA thesis.

Schepker, D. J. (2012). Role of Executive Capital and the Market for Alternative Candidates in CEO Dismissal and Labor Market Consequences for Dismissed Chief Executives. University of Kansas, USA. Retrieved from http://citeseerx.ist.psu.edu/viewdoc/download?doi=10.1.1.1015.1429\&rep=rep1\&type=pdf

Shah, P., \& Arora, P. (2014). M\&A Announcements and Their Effect on Return to Shareholders: An Event Study. Journal of Accounting and Finance Research, 3(2), 170-190. Retrieved from http://sciedu.ca/journal/index.php/afr/article/download/4684/2805

St-onge, S., Magnan, M., Thorne, L., \& Raymond, S. (2010). Effectiveness of Stock Option Plans: A Field Investigation of Senior Executives. Journal of Management Inquiry, 10(3), 250-266.

Sweeney, D. J (2006). Fundamentals of Business Statistics. International Students Edition, Thomson South Western Publishers, USA.

Wiersema, M. (2002). Holes at the Top: Why CEO Firings Backfire. Harvard Business Review, 80(12), 70-77. Retrieved from https://hbr.org/2002/12/holes-at-the-top-why-ceo-firings-backfire

Wu, X. (2014). Timely vs. Delayed CEO Resignation and Company Performance. Unpublished Masters Thesis, The John Molson School of Business, Concordia University, Canada.

Appendix 1: Sample of CEO Dismissal, retirement and resignation Events in Kenyan Listed Firms

\begin{tabular}{llll}
\hline Chief Executive Officer & Industry & Date Of Departure & Departure Event \\
\hline CEO 1 & Commercial Bank & $17^{\text {th }}$ January 2003 & Dismissal \\
CEO 2 & Cement Company & $15^{\text {th }}$ July 2010 & Dismissal \\
CEO 3 & Vehicle Assembly firm & $17^{\text {th }}$ March 2011 & Dismissal \\
CEO 4 & Media Company & $4^{\text {th }}$ May 2005 & Retirement \\
CEO 5 & Tea and Coffee Export Firm & October 1, 2008 & Retirement \\
CEO 6 & Commercial Bank & $1^{\text {st }}$ May 2007 & Retirement \\
CEO 7 & Commercial Bank & $1^{\text {st }}$ November 2006 & Resignation \\
CEO 8 & Commercial Bank & $26^{\text {th }}$ July 2006 & Resignation \\
CEO 9 & Manufacturing Firm & $1^{\text {st }}$ December 2006 & Resignation \\
\hline
\end{tabular}




\section{Copyrights}

Copyright for this article is retained by the author(s), with first publication rights granted to the journal.

This is an open-access article distributed under the terms and conditions of the Creative Commons Attribution license (http://creativecommons.org/licenses/by/4.0/). 